\title{
Effect of Different Levels and Sources of Sulphur on Growth and Productivity of Sesame under Sandy Soils of Western Rajasthan
}

\author{
K.C. Yadav ${ }^{1 *}$, Yogesh Sharma ${ }^{1}$, S.R. $\operatorname{Yadav}^{1}$ and G.L. Dhaker ${ }^{2}$ \\ ${ }^{1}$ Department of Soil Science \& Agricultural Chemistry, SKRAU, Bikaner, India \\ ${ }^{2}$ Department of Soil Science, SKNAU, Jobner, SKNAU, Jobner, India \\ *Corresponding author
}

\section{A B S T R A C T}

\begin{tabular}{|l|}
\hline Key w or d s \\
Sulphur, Sesame, \\
Gypsum, Elemental \\
Sulphur (ES), \\
Single Super \\
Phosphate (SSP) \\
\hline Article Info \\
\hline Accepted: \\
07 June 2019 \\
Available Online: \\
10 July 2019 \\
\hline \hline
\end{tabular}

An experiment was carried out at the Instructional farm, College of Agriculture, Bikaner during Kharif 2017-18 on loamy sand soil. The experiment comprising of four sources (Gypsum, ES, SSP + Gypsum and SSP+ES) and four levels of sulphur (30, 45, 60 and $\left.75 \mathrm{~kg} \mathrm{ha}^{-1}\right)$ along with an absolute control (no sulphur) making 17 treatment combinations. These 17 combinations were replicated three times in factorial randomized block design. Results showed that application of sulphur through SSP + gypsum, significantly increased the dry matter accumulation at 30,60 DAS and at harvest. These sources @ $60 \mathrm{~kg} \mathrm{~S} h a^{-1}$ except plant stand at 30 DAS and at harvest. gave significantly higher dry matter accumulation at 30,60 DAS and at harvest, plant height at harvest over control and which was statistically at par with $75 \mathrm{~kg} \mathrm{~S} \mathrm{ha}^{-1}$. Application of sulphur up to $60 \mathrm{~kg} \mathrm{~S} \mathrm{ha}^{-1}$ increased the biological yield of sesame significantly over preceding levels. The increase in biomass with this level was 12.51 and 7.88 percent over 30 and $45 \mathrm{~kg} \mathrm{~S} \mathrm{ha}^{-1}$, respectively. Maximum biological yield was recorded in $75 \mathrm{~kg} \mathrm{~S} \mathrm{ha}^{-1}$ treatment which was statistically at par with $60 \mathrm{~kg} \mathrm{~S} \mathrm{ha}^{-1}$. Application of sulphur through SSP + gypsum produced significantly higher biological yield $\left(3647.7 \mathrm{~kg} \mathrm{ha}^{-1}\right.$ ) which was $8.48,7.66$ and 6.60 percent higher over ES, ES+SSP and gypsum, respectively. Application of SSP + gypsum significantly increased the plant height and dry matter accumulation and crop productivity over ES+SSP, gypsum and ES. Among the sources and levels of sulphur application, SSP + gypsum recorded higher total biomass up to $75 \mathrm{~kg} \mathrm{~S} \mathrm{ha}^{-1}$.

\section{Introduction}

Sesame (Sesamum indicum L.) also called as "Queen of oil seeds" has been known to be one of the earliest domesticated edible oilseeds used by the mankind. It is an important edible oil seed crop next to groundnut and rapeseed-mustard. It's oil content generally varies from 46 to 52 percent and protein content 18-20 percent. Globally, sesame is grown on more than 7.0 million hectares with production of 4.0 million tonnes and productivity of $535 \mathrm{~kg} \mathrm{ha}^{-1}$. India is the largest producer of sesame in the world. It is cultivated on 2.0 mha with total production of $0.81 \mathrm{mt}$. The average productivity of the crop is $405.5 \mathrm{~kg} \mathrm{ha}^{-1}$ (Anonymous, 2014-15). In Rajasthan, it is successfully cultivated in Pali, Sirohi, Karauli, Sawaimadhopur, Hanumangarh, Bhilwara, Nagaur, Jodhpur and Jhunjhunu districts. Despite of being such an important sesame growing state, the average 
productivity in Rajasthan is very low in comparison to global as well as national level. Cultivation of crop on marginal and submarginal lands of poor fertility under rain fed condition, low and scanty rainfall, poor agronomic practices and inadequate or even no use of fertilizers are the major factors responsible for low productivity. Sulphur is an essential plant nutrient. Research work done in different parts of the country indicates that application of sulphur is highly profitable and seems to be essential for boosting the crop production. Available sulphur in soil is frequently ranged between 5-10 ppm in light textured soils of Rajasthan. In such soils, each unit of sulphur applied can augment the supply of edible oil by 3.5 units (Tandon, 1995). It has been reported that, on an average, production of one tonne of oilseed requires $12 \mathrm{~kg}$ sulphur (Jamal et al., 2010). This suggests that economic crop production cannot be expected from the fertilizers devoid of sulphur.

Sulphur plays an important role in many physiological processes of plant like synthesis of sulphur containing amino acids (cystine, cystein and methionine), vitamins (biotin and thiamine), co-enzyme-A and chlorophyll and metabolism of carbohydrates, protein and fats. It also helps in synthesis of glucosides in sesame oil and increasing the oil quality in oilseed crops. Sulphur also has an important role in development of root system and increases drought and cold tolerance in crops due to disulphide linkage. It helps in control of diseases and pests and hastens the decomposition of crop residues. A number of substances supplying sulphur are available in the market. The direct source of sulphur is elemental sulphur (ES) which is somewhat costlier. Gypsum is another material, containing 18 per cent sulphur, huge deposits of which are found in the state of Rajasthan and being excavated at large scale. Single super phosphate (SSP) is another source containing 12 per cent sulphur in addition of phosphorus. Thus, it is wise to select a relatively cheaper and more effective source of sulphur. Taking into consideration the above facts, the present investigation was planned to evaluate effect of different levels of sulphur and its sources on productivity of sesame in sandy soils of western Rajasthan.

\section{Materials and Methods}

The experiment was conducted at research farm of College of Agriculture, Bikaner during kharif 2017-18. Geographically, it is situated at $28.01^{\circ} \mathrm{N}$ latitude and $73.22^{\circ} \mathrm{E}$ longitude at an altitude of $234.7 \mathrm{~m}$ above mean sea level. The relative humidity of the locality fluctuates between 16.7 to 85.9 percent, total rainfall was $168.3 \mathrm{~mm}$ and average maximum and minimum temperature $47.1^{\circ} \mathrm{C}$ and $16.8^{\circ} \mathrm{C}$ respectively in kharif 2017 18.

The experiment comprises four sources of sulphur (Gypsum, Elemental Sulphur, Single Super Phosphate + Gypsum and Single Super Phosphate + Elemental Sulphur) and four levels of sulphur (30, 45, 60 and $\left.75 \mathrm{~kg} \mathrm{ha}^{-1}\right)$ along with an absolute control (no sulphur) making 17 treatment combinations. Dry matter accumulation calculate by randomly selected spots from each plot was recorded at 30, 60 DAS and at harvest stage. Plants were uprooted randomly from 3 spots of each plot. After removal of root portion, the samples were first air dried for some days and finally dried in an electric oven at $70^{\circ} \mathrm{C}$ till a constant weight was achieved. The weight was recorded and expressed as average dry matter plant $^{-1}(\mathrm{~g})$. At maturity, crop was harvested separately from each plot. The harvested produce of each plot was tied up in bundles, tagged and allowed to sun dry on threshing floor. After drying, the bundles were weighed for biological yield. Threshing and winnowing was done manually. After cleaning, the final 
biomass per plot was recorded and converted into $\mathrm{kg} \mathrm{ha}^{-1}$.

Experimental data recorded in various observations were statistically analysed with the help of Fisher's analysis of variance technique (Fisher, 1950). The critical difference (CD) for the treatment comparisons were worked out wherever the variance ratio (F test) was found significant at 5\% level of significance.

\section{Results and Discussion}

\section{Effect of sulphur levels on growth parameters}

Results showed that the effect of different levels of sulphur application significantly influenced all experiment traits except plant population at 30 DAS and at harvest stages. Progressive increase in level of sulphur significantly improved the plant height of sesame up to $60 \mathrm{~kg} \mathrm{Sha}^{-1}$ and was at par with $75 \mathrm{~kg} \mathrm{~S} \mathrm{ha}{ }^{-1}$. Application of $60 \mathrm{~kg} \mathrm{~S} \mathrm{ha}{ }^{-1}$ increased the plant height by 23.70 and 08.77 percent over 30 and $45 \mathrm{~kg} \mathrm{~S} h a^{-1}$, respectively. Progressive increase in level of sulphur significantly also improved the dry matter accumulation of sesame up to $75 \mathrm{~kg} \mathrm{~S} \mathrm{ha}^{-1}$ at 30, 60 DAS and harvest stages, but this level was statistically at par with $60 \mathrm{~kg} \mathrm{~S} \mathrm{ha}^{-1}$ at 30 and 60 DAS over preceding level. The percent increase due to $75 \mathrm{~kg} \mathrm{~S}^{-1}$ was $7.60,3.65$ and 1.19 per cent at 30 DAS and $8.58,6.54$ and 3.56 per cent at 60 DAS and 16.59, 10.03 and 3.92 percent at harvest stages, respectively over 30,45 and $60 \mathrm{~kg} \mathrm{~S} \mathrm{ha}^{-1}$. Significant increase in plant height and dry matter accumulation was observed due to the application of sulphur upto $60 \mathrm{~kg} \mathrm{ha}^{-1}$ (Table 1 ), however and plant population was not influenced by the sulphur levels. It is because of the fact that application of sulphur has been reported to improve not only the availability of sulphur itself but of other nutrients too, which are considered important for the growth and development of plant. Sulphur has also been reported to help in lowering the soil $\mathrm{pH}$, which is the main reason for greater availability and mobility of nutrients especially $\mathrm{P}, \mathrm{Fe}, \mathrm{Mn}$, and $\mathrm{Zn}$ (Hilal et al., 1992). Sulphur in the form of sulphate is involved in various metabolic and enzymatic activities of plant. It is also a constituent of glutathione, a compound supposed to play part in plant respiration and synthesis of oils (Jordon and Reisenaur, 1957). The profound influence of sulphur fertilization on plant height could be attributed to increased metabolic processes in plants which seem to have promoted meristematic activities causing higher apical growth and expansion of photosynthetic surface. Thus, it is obvious that the improved growth and development of the crop plants in the present investigation might be the result of enhanced metabolic activities and photosynthetic rate resulting in improvement in plant height and ultimately the accumulation of dry matter at the successive growth stages. The higher content of sulphur in plants is known to have role in better development and thickening of xylem and collenchymas tissues. The similar results were also reported by Sarkar and Saha (2005), Chaudhari and Patel (2007), Murmu et al., (2015) and Kumar et al., (2017).

\section{Effect of Sulphur levels on crop productivity}

A perusal of data (Table 1) showed that application of sulphur up to $60 \mathrm{~kg} \mathrm{~S} \mathrm{ha}{ }^{-1}$ increased the biological yield of sesame significantly over preceding levels. The increase in biomass with this level was 12.51 and 7.88 percent over 30 and $45 \mathrm{~kg} \mathrm{~S} h a^{-1}$, respectively. Maximum biological yield was recorded in $75 \mathrm{~kg} \mathrm{~S} \mathrm{ha}^{-1}$ treatment which was statistically at par with $60 \mathrm{~kg} \mathrm{~S}^{-1}$. Every increase in level of sulphur upto $60 \mathrm{~kg} \mathrm{ha}^{-1}$ recorded significant improvement in total 
biomass. The improvement in total biomass seems to be due to the balanced nutritional environment. Another probable reason could be efficient and greater partitioning of metabolites and adequate translocation of nutrients towards the developing reproductive structures i.e. sinks.

\section{Effect of sulphur sources on growth parameters}

Effect of different sources of sulphur application significantly influenced all treatments except plant population at 30 DAS and at harvest stages. Application of sulphur through SSP + gypsum was found as the most effective source in enhancing plant height of sesame. This source of sulphur increased the plant height by $6.42,5.90$ and 5.05 percent over ES, SSP+ES and gypsum, respectively. A further perusal of data (Table 1 and Fig. 1) showed that there was non-significant effect of different sources of sulphur on dry matter accumulation at 30 DAS, but, different sources of sulphur significantly affected the dry matter accumulation at 60 DAS and at harvest. The maximum dry matter of 9.59 and $12.77 \mathrm{~g} \mathrm{plant}^{-1}$ was obtained under SSP + gypsum which was 5.50 and 3.74 per cent more than gypsum, 6.44 and 4.76 per cent more than ES and 5.73 and 4.24 per cent more than SSP+ES at 60 DAS and harvest stage, respectively. It is apparent from data (Table 1) that plant height and dry matter accumulation significantly increased under SSP + gypsum treated plots at all the growth stages over control, ES, SSP+ES and gypsum. Higher plant height ascribed to addition of SSP + gypsum might be due to higher availability of sulphur as compared to other sources. It was probably due to successive increase in cell multiplication, elongation and expansion throughout the entire period of crop upto maturity. This might also be ascribed to adequate supply of sulphur that resulted in higher production of photosynthates which ultimately increased the plant growth and growth attributes. Another reason for enhancement of growth parameters might be due to increased uptake of nitrogen, sulphur and phosphorus which have resulted into larger photosynthesizing surface and accelerated the process of formation and translocation of photosynthates and hence overall development of the plant.

Fig.1 Effect of sulphur levels and its sources on dry matter accumulation at 30, 60 DAS and at harvest

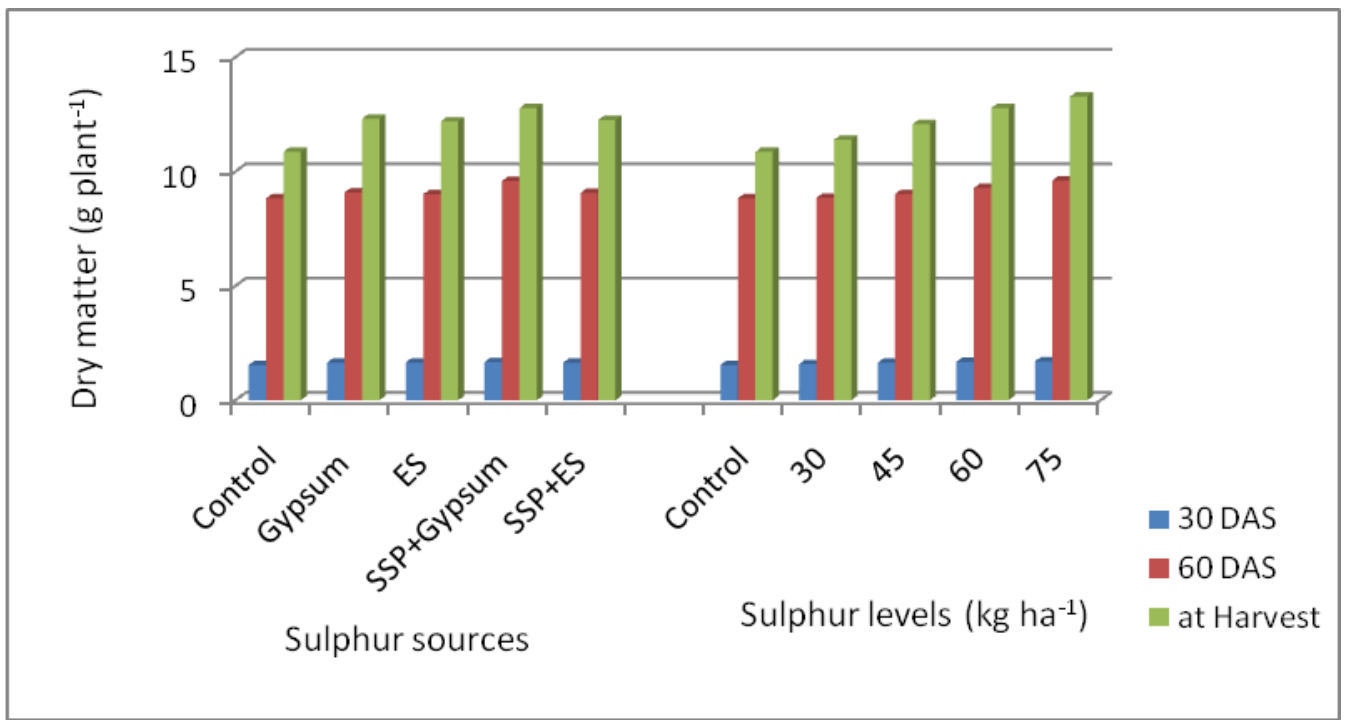


Table.1 Effect of sulphur levels and its sources on plant population $\mathrm{m}^{2}$ (30 DAS and at harvest), plant height at harvest, dry matter accumulation (30,60 DAS and at harvest) and total biomass

\begin{tabular}{|c|c|c|c|c|c|c|c|}
\hline \multirow[t]{2}{*}{ Treatments } & \multicolumn{2}{|c|}{ Plant population } & \multirow{2}{*}{$\begin{array}{c}\text { Plant } \\
\text { height } \\
(\mathrm{cm})\end{array}$} & \multicolumn{3}{|c|}{ Dry matter (g plant $\left.{ }^{-1}\right)$} & \multirow{2}{*}{$\begin{array}{c}\text { Total } \\
\text { Biomass } \\
\left(\mathrm{kg} \mathrm{ha}^{-1}\right)\end{array}$} \\
\hline & $\begin{array}{c}\text { 30 } \\
\text { DAS }\end{array}$ & Harvest & & $\begin{array}{c}30 \\
\text { DAS }\end{array}$ & $\begin{array}{c}60 \\
\text { DAS }\end{array}$ & Harvest & \\
\hline \multicolumn{8}{|c|}{ Sulphur sources } \\
\hline Gypsum & 32.50 & 30.00 & 159.63 & 1.65 & 9.09 & 12.31 & 3421.7 \\
\hline ES & 30.00 & 29.50 & 157.56 & 1.65 & 9.01 & 12.19 & 3362.6 \\
\hline SSP+Gypsum & 33.25 & 30.00 & 167.69 & 1.67 & 9.59 & 12.77 & 3647.7 \\
\hline SSP+ES & 31.51 & 29.00 & 158.36 & 1.64 & 9.07 & 12.25 & 3388.1 \\
\hline $\mathrm{SEm} \pm$ & 0.905 & 0.672 & 1.355 & 0.027 & 0.156 & 0.145 & 51.5 \\
\hline CD at $5 \%$ & NS** & $\mathrm{NS} * *$ & 3.903 & NS** & 0.450 & 0.419 & 148.3 \\
\hline \multicolumn{8}{|c|}{ Sulphur levels $\left(\mathrm{kg} \mathrm{ha}^{-1}\right)$} \\
\hline 30 & 31.58 & 29.42 & 139.19 & 1.58 & 8.85 & 11.39 & 3192.3 \\
\hline 45 & 31.84 & 29.67 & 158.30 & 1.64 & 9.02 & 12.07 & 3329.6 \\
\hline 60 & 31.87 & 29.75 & 172.18 & 1.68 & 9.28 & 12.78 & 3591.7 \\
\hline 75 & 31.98 & 29.67 & 173.57 & 1.70 & 9.61 & 13.28 & 3706.5 \\
\hline $\mathrm{SEm} \pm$ & 0.905 & 0.672 & 1.355 & 0.027 & 0.156 & 0.145 & 51.5 \\
\hline CD at $5 \%$ & NS** & NS** & 3.903 & 0.078 & 0.450 & 0.419 & 148.3 \\
\hline Control & 31.00 & 29.00 & 132.84 & 1.54 & 8.83 & 10.86 & 2973.0 \\
\hline $\begin{array}{l}\text { Sulphur } \\
\text { treatments }\end{array}$ & 31.82 & 29.63 & 160.81 & 1.65 & 9.19 & 12.38 & 3455.0 \\
\hline F test & NS** & NS** & $\mathrm{S}^{*}$ & $\mathrm{~S}^{*}$ & $S^{*}$ & S* & S* \\
\hline
\end{tabular}

*Significant, **Non-Significant

Higher dry matter accumulation with gypsum source was also reported by Kumar et al., (2011) in sunflower, Yadav and bohra (2008), Rani et al., (2009) and higher plant height with gypsum by Rao et al., (2013) in groundnut, Shinde et al., (2011), and Tripathi et al., (2007) along with SSP.

Effect of sulphur sources on crop productivity

A perusal of data (Table 1) showed that application of sulphur through SSP + gypsum produced significantly higher biological yield $\left(3647.7 \mathrm{~kg} \mathrm{ha}^{-1}\right)$ which was $8.48,7.66$ and 6.60 percent higher over ES, ES+SSP and gypsum, respectively. The significant increase in total biomass under SSP + gypsum might be attributed to the higher solubility and easy availability of $\mathrm{SO}_{4}{ }^{-2}$ sulphur present in SSP + gypsum as compared to only gypsum and "sulphide" form of sulphur present in elemental sulphur which essentially requires its oxidation to be converted into $\mathrm{SO}_{4}^{-2}$ form of sulphur prior to be finally absorbed by the plant. Results of Pati et al., (2011) also revealed that total biomass of sesame increased significantly with the source supplying $\mathrm{SO}_{4}^{-2}-\mathrm{S}$.

\section{Sulphur fertilization over control}

Results revealed that different levels as well as sources of sulphur could not bring 
significant variation in plant population of sesame at 30 DAS and at harvest stages (Table 1). Average of different of sources and levels of sulphur significantly increased the plant height by 21.05 per cent over control, dry matter accumulation varied significantly at 7.14, 4.07 and 14.00 per cent over control respectively at 30, 60 DAS and harvest and total biomass of sesame by 16.21 per cent over control.

Application of SSP + gypsum significantly increased the plant height and dry matter accumulation at harvest over ES+SSP, gypsum and ES. The increasing levels of sulphur up to $60 \mathrm{~kg} \mathrm{~S} \mathrm{ha}$ significantly increased the plant height at harvest and dry matter accumulation per plant at all the stages. However, the higher level was found at par with $60 \mathrm{~kg} \mathrm{~S} \mathrm{ha}^{-1}$. The plant stand at 30 DAS and at harvest was observed nonsignificant. Among the sources and levels of sulphur application, SSP + gypsum recorded higher total biomass up to $75 \mathrm{~kg} \mathrm{~S} \mathrm{ha}^{-1}$.

\section{References}

Anonymous, 2014-15. Directorate of Economics and Statistics, Department of Agriculture and Cooperation, 161166.

Chaudhari, S.R. and Patel, D.B. 2007. Response of sesame (Sesamum indicum L.) to different levels of phosphorus and sulphur under north Gujarat agro climatic conditions. Gujarat Agriculture University Research Journal, 32: 31-35.

Fisher, R.A. 1950. Statistical Methods for Research Workers. Oliver and Boyd, Edinburg, Landon.

Hilal, M.H., Fattah, A.A. and Korkar, S.A. 1992. Effect of fine and granular sulphur application on root depth and yield of lupinus in sandy soils. Proceedings Middle East Sulphur Symposium, Feb. 12-16, Cairo Egypt,
TSI, Washington, USA. 207-216.

Jamal, A., Moon, Y.S. and Abdin, M.Z. 2010. Sulphur a general overview and interaction with nitrogen. Australian Journal of Crop Science, 4: 523-529

Jordon, H.V. and Reisenaur, H.M. 1957. Sulphur and soil fertility. (In) Soil Year Book Agriculture, USDA, Washington: 107-111.

Kumar, S., Meena, R.S., Yadav, G.S. and Pandey, A. 2017.Response of sesame (Sesamum indicum L.) to sulphur and lime application under soil acidity. International Journal of Plant \& Soil Science, 14: 1-9.

Kumar, S., Tewari, S.K. and Singh, S.S. 2011. Effect of sources and levels of sulphur and spacing on the growth, yield and quality of spring sunflower (Helianthus annuus). Indian Journal of Agronomy, 56(3): 242-246.

Murmu, S., Murmu, K. and Satapathy, M. 2015. Effect of sulphur fertilization on growth, yield and quality of sesame (Sesamum indicum L.) in mid central zone of Odisha, International Journal of Bio-resource, Environmental and Agricultural Science, 1(1): 5-12.

Pati, B.K., Patra, P., Ghosh, G.K., Mondal, S., Malik, G.C. and Biswas, P.K. 2011. Efficacy of phosphogypsum and magnesium sulphate as sources of sulphur to sesame (Sesamum indicum L.) in red and lateritic soils of West Bengal. Journal of Crop and Weed, 7: 133-135.

Rani, K.U., Sharma, K.L., Nagasri, K., Srinivas, K., Murthy, T.V., Shankar, G.R.M., Korwar, G.R., Sankar, K.S., Madhavi, M. and Grace, J.K. 2009. Response of sunflower to sources and levels of sulphur under rainfed semiarid tropical conditions. Communications in Soil Science and Plant Analysis, 40(17/18): 2926-2944.

Rao, K.T., Rao, A.U. and Sekhar, D. 2013. 
Effect of sources and levels of sulphur on groundnut. Journal of Academia and Industrial Research, 2(5): 268-270.

Sarkar, R.K. and Saha, A. 2005. Analysis of growth and productivity of sesame (Sesamum indicum L.) in relation to nitrogen, sulphur and boron. Indian Journal of Plant Physiology, 10(4): 333-337.

Shinde, S.D., Raskar, B.S. and Tamboli, B.D. 2011. Effect of spacing and sulphur levels on productivity of sesame (Sesamum indicum L.) under summer condition. Journal of Maharashtra Agricultural Universities, 36(1): 28-31. agricultural production in India. Fertilizer development consultation organization, New Delhi.

Tripathi, M.L., Rajput, R.L. and Chauratia, S.K. 2007. Effect of sources and levels of sulphur on yield and economics of sesame. Advances in Plant Science, 20: 501-502.

Yadav, R.T. and Bohra, J.S. 2008. Response of sulphur levels and sources at different fertility levels on growth and yield attributing characters of Indian mustard [Brassica juncea (L.) Czern \& Coss]. Annals of Agri Bio Research, 14(2): 111-113.

Tandon, H.L.S. 1995. Sulphur research and

\section{How to cite this article:}

Yadav, K.C., Yogesh Sharma, S.R. Yadav and Dhaker, G.L. 2019. Effect of Different Levels and Sources of Sulphur on Growth and Productivity of Sesame under Sandy Soils of Western Rajasthan. Int.J.Curr.Microbiol.App.Sci. 8(07): 588-594.

doi: https://doi.org/10.20546/ijcmas.2019.807.073 